\title{
Revalidation of game for teaching blood pressure auscultatory measurement: a pilot study
}

\author{
Revalidação de jogo para ensino da medida auscultatória de pressão arterial: estudo-piloto \\ Revalidación del juego para enseñar a medir la presión arterial por la auscultación: estudio piloto
}

Margarete Consorti Bellan', Vanessa Cortez Alves', Mayza Luzia dos Santos Neves', José Luiz Tatagiba Lamas'

'Universidade Estadual de Campinas, School of Nursing, Postgraduate Program in Nursing. Campinas, São Paulo, Brazil.

\section{How to cite this article:}

Bellan MC, Alves VC, Neves MLS, Lamas JLT. Revalidation of game for teaching blood pressure auscultatory measurement: a pilot study. Rev Bras Enferm [Internet]. 2017;70(6):1159-68.

DOI: http://dx.doi.org/10.1590/0034-7167-2016-0578

Submission: 12-12-2016 Approval: 04-04-2017

\begin{abstract}
Objective: To adapt a pre-existing educational game, making it specific to the teaching of blood pressure auscultatory measurement, and to apply this game in a pilot study. Method: The original game cards were altered by the authors and submitted to content validation by six experts in the field. After redesigns, the game was applied to 30 subjects, who answered a questionnaire (pre-test and post-test) on auscultatory measurement. Data were analyzed descriptively and by the paired Student's t-test and paired Wilcoxon test. Results: Throughout the content validation process, 17 of the 28 original cards were modified. Of these 17 cards, 13 obtained $80 \%$ agreement, and the rest were modified according to the judges' suggestions. The obtained grades significantly increased between pre- and the post-test. Conclusion: It was concluded that the reformulated game presented satisfactory evidence of content validity. Its use as a teaching-learning method was effective for this sample.

Descriptors: Determination of Blood Pressure; Games and Toys; Education in Nursing; Educational Technology; Experimental Games.
\end{abstract}

\section{RESUMO}

Objetivo: Adaptar um jogo educativo pré-existente, tornando-o específico para o ensino da medida auscultatória da pressão arterial, e aplicar esse jogo em estudo-piloto. Método: As cartas do jogo original foram alteradas pelos autores e submetidas a validação de conteúdo por seis especialistas na área. Após reformulações, o jogo foi aplicado a 30 sujeitos, que responderam a um questionário (pré-teste e pós-teste) sobre medida auscultatória. Os dados foram analisados descritivamente e pelos testes $t$ de Student pareado e Wilcoxon pareado. Resultados: Em todo o processo de validação de conteúdo, foram modificadas 17 das 28 cartas originais. Destas 17, 13 obtiveram $80 \%$ de concordância, e as demais foram modificadas conforme sugestões dos juízes. As notas obtidas aumentaram significantemente entre o pré-teste e o pós-teste. Conclusão: Concluiu-se que o jogo reformulado apresentou evidências satisfatórias de validade de conteúdo. Sua utilização enquanto método de ensino-aprendizagem foi eficaz para esta amostra.

Descritores: Determinação da Pressão Arterial; Jogos e Brinquedos; Educação em Enfermagem; Tecnologia Educacional; Jogos Experimentais.

\section{RESUMEN}

Objetivo: Adaptar un juego educativo ya existente, al dejarlo específico para enseñar a medir la presión arterial por la auscultación, y aplicarlo en un estudio piloto. Método: Las cartas del juego original fueron cambiadas por los autores y sometidas a la validación de contenido por seis expertos en el área. Tras las reformulaciones, se aplicó el juego a treinta personas, que contestaron preguntas (antes de la prueba y después de la prueba) acerca de la medición por la auscultación. Se analizaron los datos descriptivamente y por intermedio de las pruebas t de Student pareada y Wilcoxon pareada. Resultados: Durante el proceso de validación de contenido, se cambiaron 17 de 28 cartas originales. De las diecisiete, trece tuvieron el 80\% de concordancia, y las demás fueron cambiadas según las sugerencias de los expertos. Las notas obtenidas aumentaron significativamente entre antes de la prueba y 
después de la prueba. Conclusión: Se concluye que el juego reformulado presentó satisfactorias evidencias para la validación de contenido. Su uso mientras método de enseñanza-aprendizaje fue eficaz para esta muestra.

Descriptores: Determinación de la Presión Arterial; Juegos e Implementos de Juego; Educación en Enfermería; Tecnología Educacional; Juegos Experimentales.

\section{CORRESPONDING AUTHORＭargarete Consorti BellanＥ-mail: margaretebellan@uol.com.br}

\section{INTRODUCTION}

Systemic Arterial Hypertension (SAH) is one of the most important risk factors for the development of vascular lesions, functional and/or structural changes of target organs and metabolic changes. Its early detection, control and treatment are essential to reduce the occurrence of possible cardiovascular events ${ }^{(1-3)}$.

Measurement of blood pressure (BP) by the indirect method with auscultatory technique is recommended on the $7^{\text {th }}$ Brazilian Hypertension Guideline, being the most used technique in health services ${ }^{(1)}$. The performance of error-free technique is essential to obtain reliable values, and the nursing staff plays a key role in performing the BP measurement. However, research indicates significant gaps on the indirect BP measurement regarding the technique and the instrumental, which could hinder the correct diagnosis ${ }^{(3-4)}$. These discrepancies may be related to a common practice and to the need of strengthening service education programs ${ }^{(4-5)}$.

To facilitate learning, recreational activities are offered, such as educational games, which help in the construction of knowledge, cognitive development, skills and ethical attitudes, in a relaxed way ${ }^{(4)}$. Thus, we highlight the importance of using the playful method in the teaching-learning process for the expansion of knowledge in the area of nursing ${ }^{(4)}$.

The literature search showed the existence of a game already validated, developed in such a way that it could be used as a strategy for fixing the technique of indirect BP measurement $^{(6)}$. Its analysis and application, however, show that the game goes beyond these goals, and might lose its specificity. The aim of this study was to revalidate the content of this educational game that already exists, in order to make it specific for teaching the auscultatory technique of BP measurement.

\section{OBJECTIVE}

To perform the adaptation and revalidation of the contents of an educational game developed with the objective of fixing the technique of indirect BP measurement.

\section{Specific objectives}

To modify the game cards, with the purpose of making it more specific as a teaching-learning strategy of the auscultatory technique of BP measurement; to validate the content of the game cards after their modification; to apply the final product in an appropriate sample for a pilot study.

\section{METHOD}

\section{Ethical aspects}

The project was approved by the Research Ethics Committee of the Institution.

\section{Study design, location and period}

This is a methodological cross-sectional study, developed in three steps from October 2014 to July 2016 at a university in the countryside of the state of São Paulo.

Population or sample and inclusion and exclusion criteria

Participants were 30 individuals, 10 professionals who participate as members of the research group in blood pressure studies and 20 students of the $4^{\text {th }}$ year of the Nursing Program who attended the summer program, which addressed aspects of blood pressure measurement.

\section{Study protocol}

This study was conducted in three steps. The first step was a bibliographic survey of educational games developed with focus on the teaching-learning of BP measurement, and selection of an article that describes the methodological steps of building an educational game for this technique, developed at the Federal University of Ceará(6). After obtaining the authors' authorization to modify the game, the second stage of validation of the content of the alterations proposed in the game was held. The original game is composed of two sets of cards: a) Playing cards (28): they contain photographs of unhealthy habits, related to risk factors for hypertension, and only one of healthy habits, related to the hypertension control, used to start the game; b) Bonus, reverse and luck cards (28): they contain situations related to blood pressure measurement and treatment of hypertension.

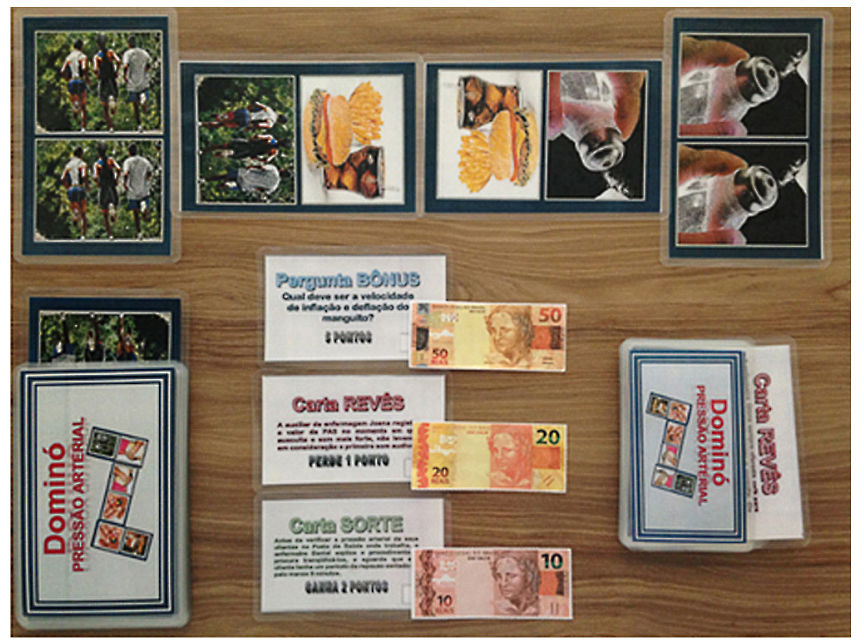

Source: The cards with images used in the game of dominoes were developed and validated by Andrade et al. (2012) and did not suffer changes in this version, Campinas, Brazil, 2016

Figure 1 - Educational game cards 
Initially, the cards were changed from information of the literature on the BP auscultatory measurement ${ }^{(2)}$. We elaborated a spreadsheet in Microsoft Excel ${ }^{\circledR}$ composed of a column with the wording of each bonus, reverse and luck card that compose the original game; a column with the new content of cards that were modified; another column with the justification of the content change; one last column with the bibliography used. This file was sent by e-mail to six judges, experts in the subject, as recommended for content validation ${ }^{(7)}$, along with a document that contained the game objective. On the spreadsheet, below the text of each card, a space was added for evaluation, with the codes A (I agree), PA (I partially agree) and $\mathrm{D}$ (I disagree), in addition to a space in which the evaluators could present their suggestions. The agreement among the judges should be of at least $80 \%$ for the content to be considered valid ${ }^{(7-9)}$. Suggestions were analyzed by researchers, generating new changes of the produced material.

In the third step (pilot study), Domino was played by 30 individuals after they agreed to participate in the research and signed the Informed Consent Form. In every application of the game there was a moderator (one of the research authors, properly qualified) and two or three players. Before the contact with the game, we held a prior evaluation (pre-test) of knowledge about the technique of indirect BP measurement with the participants, using a self-answered questionnaire developed by Almeida ${ }^{(5)}$, adapted to specifically evaluate the previous knowledge about auscultatory measurement. It contains 15 questions, divided into three domains (D1 - five questions related to the BP measurement; D2 - four questions related to instruments used during the measurement; D3 - six questions related to the indirect method). These were multiple choice questions. Besides them, there were three self-assessment questions, answered by using Likert-type scales. After application of the game, the same questionnaire was answered (post-test). A value was assigned to each of the 15 questions from the three domains, so that the total score was 10 . The three self-assessment questions had their scores set by the scale used.

After application of the pre-test, the moderator explained the objectives and rules of the game and distributed the cards among the participants. The game was similar to Domino, however, when each card was placed on the table, the moderator would read the content of a card from the previously mixed pile of bonus, reverse and luck cards, so that the player could answer the question enunciated there. The game would only end after reading all the bonus, reverse and luck cards, and the player who would have accumulated more points at the end wins.

\section{Analysis of the results and statistics}

Descriptive statistical and inferential analysis was performed using the program SPSS 20.0. For comparison of the self-attributed grades in the pre- and post-test, as well as of the questionnaire score, the paired Student's t-test and paired Wilcoxon test were used, considering $\mathrm{p}$ values $<0.05$ as significant .

\section{RESULTS}

\section{Validation of cards}

Seventeen cards were modified from the original game to achieve the objectives of this study. The final number remained at 28 .

Each card modified was assessed by six judges. three of them obtained $67 \%$ agreement, and only one reached $50 \%$. These cards were modified according to the evaluators' suggestions. The other 13 cards obtained more than $80 \%$ agreement, and only minor modifications that researchers found relevant were made, according to suggestions from judges and the study objectives. Chart 1 presents the content of the game cards, indicating which ones were modified.

Chart 1 - Original and modified content of the bonus, reverse and luck cards, with indication of reasons and references used for the changes made, Campinas, São Paulo, Brazil, 2016

\begin{tabular}{|l|l|l|l|}
\hline No. & Original card & Modified card & Reason \\
\hline $\mathbf{1}$ & $\begin{array}{l}\text { The nurse Claudia always measures } \\
\text { the blood pressure three times and } \\
\text { calculates the average of the last } \\
\text { two measurements If the difference } \\
\text { between them is higher than 20 } \\
\text { mmHg, she measures a fourth } \\
\text { time, by the average of the last two, } \\
\begin{array}{l}\text { as the V Hypertension Guideline } \\
\text { establishes. }\end{array}\end{array}$ & $\begin{array}{l}\text { Nurse Claudia, on the initial assessment of } \\
\text { her patients, measures the blood pressure (BP) } \\
\text { in a sitting position in both arms and, when } \\
\text { there is a difference of values, she takes the } \\
\text { subsequent measures in the arm with higher } \\
\text { value. In the following appointments, Claudia } \\
\text { measures the BP of this member at least three } \\
\text { times and considers the average of the last } \\
\text { two measurements as the real BP(1-2). }\end{array}$ & Question is not updated. \\
\hline $\begin{array}{l}\text { What is the auscultatory gap } \\
\text { method? Why does it appear? How } \\
\text { to avoid it? }\end{array}$ & $\begin{array}{l}\text { What is the auscultatory gap method? } \\
\text { Why and in which situations it appears? } \\
\text { In this case, how to detect systolic blood } \\
\text { pressure? }{ }^{(5)} .\end{array}$ & $\begin{array}{l}\text { The auscultation gap usually occurs } \\
\text { in older adults with Systemic Arterial } \\
\text { Hypertension, arteriosclerosis } \\
\text { and severe aortic stenosis. It is not } \\
\text { possible to avoid it, but it is possible } \\
\text { to estimate the Systolic BP by the } \\
\text { palpatory method, applying the } \\
\text { Osler's maneuver, in order to avoid } \\
\text { errors arising from this phenomenon. }\end{array}$ \\
\hline
\end{tabular}




\begin{tabular}{|c|c|c|c|}
\hline No. & Original card & Modified card & Reason \\
\hline 3 & $\begin{array}{l}\text { What should be the rate of inflation } \\
\text { and deflation of the cuff? }\end{array}$ & Original card maintained & l \\
\hline 4 & $\begin{array}{l}\text { João was nervous because he knew he } \\
\text { was going to check the blood pressure } \\
\text { and he smoked two cigarettes minutes } \\
\text { before the appointment and did not go } \\
\text { to the bathroom to empty his bladder. } \\
\text { The nurse, who was in a hurry, did } \\
\text { not remember to ask the necessary } \\
\text { questions and did not notice the } \\
\text { anxiety of her patient before checking } \\
\text { blood pressure. }\end{array}$ & Original card maintained & I \\
\hline 5 & $\begin{array}{l}\text { Lorena, hypertensive for many years, } \\
\text { was instructed by nurse Lúcio not } \\
\text { to ingest her antihypertensive drugs } \\
\text { before measuring her blood pressure. }\end{array}$ & $\begin{array}{l}\text { When nurse Lúcio gauges the patients' } \\
\text { blood pressure he usually places the cuff in } \\
\text { any location of the arm, without palpating } \\
\text { the brachial artery, and he uses the } \\
\text { stethoscope with strong compression in the } \\
\text { cubital fossa to better hear the beats }{ }^{(1,5)} \text {. }\end{array}$ & $\begin{array}{l}\text { Question focused on the } \\
\text { management of Arterial } \\
\text { Hypertension. Modification } \\
\text { necessary to achieve the research } \\
\text { objectives. }\end{array}$ \\
\hline 6 & $\begin{array}{l}\text { Nursing technician Ana, while } \\
\text { checking the BP of her patients, } \\
\text { neglects the technique of arm } \\
\text { circumference measurement for choice } \\
\text { of the appropriate cuff; she states that } \\
\text { cuffs with a width of more than or less } \\
\text { than the recommended do not alter the } \\
\text { values of blood pressure. }\end{array}$ & Original card maintained & l \\
\hline 7 & $\begin{array}{l}\text { Nursing auxiliary Cristina measures the } \\
\text { BP in any arm, regardless of venous } \\
\text { access, injure, decrease or loss of } \\
\text { function; when she checks the blood } \\
\text { pressure of her patients in the standing } \\
\text { position she tells them to keep the } \\
\text { extended arm on the side of the body. }\end{array}$ & Original card maintained & l \\
\hline 8 & $\begin{array}{l}\text { When the pharmacological treatment } \\
\text { was started by the physician, nurse } \\
\text { Vanda dispenses her hypertensive } \\
\text { patients from performing non- } \\
\text { pharmacological treatment. }\end{array}$ & $\begin{array}{l}\text { Nurse Carla always performs the measurement } \\
\text { of patients' brachial circumference at the } \\
\text { midpoint between the acromion and the } \\
\text { olecranon before measuring their blood } \\
\text { pressure. The chosen cuff should always } \\
\text { have the width of approximately } 40 \% \text { of this } \\
\text { circumference and involve } 80 \% \text { of the arm }{ }^{(1-2)} \text {. }\end{array}$ & $\begin{array}{l}\text { Question focused on the } \\
\text { management of Arterial } \\
\text { Hypertension. Modification } \\
\text { necessary to achieve the research } \\
\text { objectives and to have the same } \\
\text { number of cards - LUCK and } \\
\text { REVERSE. }\end{array}$ \\
\hline 9 & $\begin{array}{l}\text { Nursing technician Isabel usually } \\
\text { measures the blood pressure using } \\
\text { only the sphygmomanometer and } \\
\text { estimating the pressure by palpation } \\
\text { of the radial pulse during deflation of } \\
\text { the sphygmomanometer. }\end{array}$ & $\begin{array}{l}\text { Nursing technician Isabel usually measures } \\
\text { the Systolic and Diastolic Blood Pressure } \\
\text { using only the sphygmomanometer and } \\
\text { estimating the pressure by palpation of } \\
\text { the radial pulse during deflation of the } \\
\text { sphygmomanometer }{ }^{(1-2)} \text {. }\end{array}$ & $\begin{array}{l}\text { The question does not clarify if } \\
\text { only the systolic blood pressure } \\
\text { is determined. This form of } \\
\text { measurement may be used when it is } \\
\text { not possible to auscultate the systolic } \\
\text { pressure, but it does not allow } \\
\text { diastolic pressure identification. }\end{array}$ \\
\hline 10 & $\begin{array}{l}\text { Nursing assistant Joana registers } \\
\text { the value of the SBP at the moment } \\
\text { when she auscultates the strongest } \\
\text { sound, not taking into consideration } \\
\text { the first audible sound. }\end{array}$ & Original card maintained & l \\
\hline 11 & $\begin{array}{l}\text { Before checking the blood pressure of } \\
\text { his patients at the Health Center where } \\
\text { he works, Nurse Daniel explains the } \\
\text { procedures, tries to tranquilize them, } \\
\text { and then waits until his patient has a } \\
\text { sitting rest period of at least } 5 \text { minutes. }\end{array}$ & Original card maintained & l \\
\hline
\end{tabular}


Chart 1

\begin{tabular}{|c|c|c|c|}
\hline No. & Original card & Modified card & Reason \\
\hline 12 & $\begin{array}{l}\text { Nurse Gilberto stimulates his patients } \\
\text { to make changes in their lifestyles by } \\
\text { adopting healthier habits. }\end{array}$ & $\begin{array}{l}\text { Nurse Jonas learned that when professionals } \\
\text { measure blood pressure and use narrow } \\
\text { cuffs, in relation to the patient's arm } \\
\text { circumference, its value is overrated; and, } \\
\text { if the cuff is too wide, the BP value will be } \\
\text { underestimated }{ }^{(1-2)} \text {. }\end{array}$ & $\begin{array}{l}\text { Question focused on the } \\
\text { management of Arterial } \\
\text { Hypertension. Modification } \\
\text { necessary to achieve the research } \\
\text { objectives. }\end{array}$ \\
\hline 13 & $\begin{array}{l}\text { Nurse Marcia calibrates her } \\
\text { aneroid every year and periodically } \\
\text { checks the integrity of the rubber } \\
\text { structures of her stethoscope and } \\
\text { sphygmomanometer. }\end{array}$ & $\begin{array}{l}\text { Nurse Marcia calibrates her aneroid blood } \\
\text { pressure device every six months and } \\
\text { periodically checks the integrity of the } \\
\text { rubber structures of her stethoscope and } \\
\text { sphygmomanometer, substituting these } \\
\text { structures when needed }{ }^{(1-2)} \text {. }\end{array}$ & $\begin{array}{l}\text { According to the VI Hypertension } \\
\text { Guideline, the correct time for aneroid } \\
\text { devices calibration is every six months. } \\
\text { The interval is annual for mercury and } \\
\text { oscillometric manometers. }\end{array}$ \\
\hline 14 & $\begin{array}{l}\text { Nurse José gives special attention } \\
\text { to the blood pressure value of his } \\
\text { patients who use birth control, } \\
\text { because he knows that it raises the } \\
\text { pressure. }\end{array}$ & $\begin{array}{l}\text { Nurse José gives special attention to the blood } \\
\text { pressure value of his patients and knows } \\
\text { that the result of measurements should be } \\
\text { reported to the patient and noted without } \\
\text { rounding, with the description of the body } \\
\text { location where it was measured }{ }^{(1-2)} \text {. }\end{array}$ & $\begin{array}{l}\text { Question focused on the } \\
\text { management of Arterial } \\
\text { Hypertension. Modification } \\
\text { necessary to achieve the research } \\
\text { objectives. }\end{array}$ \\
\hline 15 & $\begin{array}{l}\text { Nurse Lígia measures the blood } \\
\text { pressure of all her patients } \\
\text { regardless if they have systemic } \\
\text { arterial hypertension or not; she } \\
\text { conducts regular monitoring of BP } \\
\text { of pregnant women during prenatal } \\
\text { care, because she knows the perils } \\
\text { of HDP. }\end{array}$ & $\begin{array}{l}\text { Nurse Lígia measures the blood pressure of all } \\
\text { patients by taking the following precautions: } \\
\text { she measures the arm circumference and } \\
\text { uses the appropriate cuff; she centralizes the } \\
\text { compressive part of the cuff on the brachial } \\
\text { artery, holds the cuff without leaving gaps and } \\
\text { respects the distance of } 2 \text { to } 3 \mathrm{~cm} \text { above the } \\
\text { cubital fossa } \\
\text { (1-2). }\end{array}$ & $\begin{array}{l}\text { Question focused on the } \\
\text { management of Arterial } \\
\text { Hypertension. Modification } \\
\text { necessary to achieve the research } \\
\text { objectives. }\end{array}$ \\
\hline 16 & $\begin{array}{l}\text { What is the concept of blood } \\
\text { pressure and why is it important to } \\
\text { check? }\end{array}$ & Original card maintained & / \\
\hline 17 & $\begin{array}{l}\text { How is blood pressure classified, } \\
\text { what are its reference values? }\end{array}$ & $\begin{array}{l}\text { The sounds auscultated on the blood } \\
\text { pressure check are of low frequency. } \\
\text { Considering this, which part of the } \\
\text { stethoscope is better suited for an accurate } \\
\text { auscultation? }{ }^{(1-2)} \text {. }\end{array}$ & $\begin{array}{l}\text { Question focused on the } \\
\text { management of Arterial } \\
\text { Hypertension. Modification } \\
\text { necessary to achieve the research } \\
\text { objectives. }\end{array}$ \\
\hline 18 & $\begin{array}{l}\text { Nurse Julia works in a hospital and, } \\
\text { when checking the blood pressure } \\
\text { of lying patients, she places them in } \\
\text { supine position, with the arm at heart } \\
\text { level in a } 45^{\circ} \text { angle. }\end{array}$ & Original card maintained & l \\
\hline 19 & $\begin{array}{l}\text { What are the guidelines nurses } \\
\text { should give their hypertensive } \\
\text { patients regarding non-drug therapy? }\end{array}$ & $\begin{array}{l}\text { Should the presence of arteriovenous fistula } \\
\text { be observed before the blood pressure } \\
\text { measurement? Why?(1-2). }\end{array}$ & $\begin{array}{l}\text { Question focused on the management } \\
\text { of Arterial Hypertension. Modification } \\
\text { necessary to achieve the research } \\
\text { objectives. }\end{array}$ \\
\hline 20 & $\begin{array}{l}\text { How to determine the values of SBP } \\
\text { and DBP? }\end{array}$ & $\begin{array}{l}\text { Korotkoff sounds are classified into five } \\
\text { phases: } \\
\text {-Phase 1: Low and discreet sound } \\
\text {-Phase 2: Sibilant, vibrant blow } \\
\text {-Phase 3: Volume increase, higher intensity } \\
\text {-Phase 4: Muffling of sounds, change of } \\
\text { timbre } \\
\text {-Phase 5: Last sound } \\
\text { In which of these phases must the Systolic } \\
\text { Blood Pressure and the Diastolic Blood } \\
\text { Pressure be determined? }{ }^{(1-2)} \text {. }\end{array}$ & $\begin{array}{l}\text { Open question that does not } \\
\text { necessarily result in response related } \\
\text { to the Korotkoff sounds }\end{array}$ \\
\hline 21 & $\begin{array}{l}\text { How to determine the point of } \\
\text { maximum cuff inflation? }\end{array}$ & Original card maintained & l \\
\hline
\end{tabular}




\begin{tabular}{|c|c|c|c|}
\hline No. & Original card & Modified card & Reason \\
\hline 22 & $\begin{array}{l}\text { What is the recommendation for the } \\
\text { correct width and length of the cuff? }\end{array}$ & $\begin{array}{l}\text { How should the mercury column device } \\
\text { calibration be checked?(10-11). }\end{array}$ & $\begin{array}{l}\text { The topic of the question is already } \\
\text { covered in another card. }\end{array}$ \\
\hline 23 & $\begin{array}{l}\text { What is the adequate position of the } \\
\text { patient during the blood pressure } \\
\text { measurement? }\end{array}$ & $\begin{array}{l}\text { What is the recommended position of } \\
\text { the patient during the blood pressure } \\
\text { measurement? } \text { ?(1-2) }^{\text {a }}\end{array}$ & $\begin{array}{l}\text { The VI Hypertension Guideline } \\
\text { makes a recommendation on the } \\
\text { patient's position. }\end{array}$ \\
\hline 24 & $\begin{array}{l}\text { Which external factors affect } \\
\text { the value of blood pressure } \\
\text { measurement? }\end{array}$ & $\begin{array}{l}\text { What type of manometer is more trusted } \\
\text { and considered the gold standard in } \\
\text { indirect measurement of blood pressure? } ?^{(1-2)} \text {. }\end{array}$ & $\begin{array}{l}\text { Non-specific question about the } \\
\text { indirect measure of BP. Modification } \\
\text { necessary to achieve the research } \\
\text { objectives. }\end{array}$ \\
\hline 25 & $\begin{array}{l}\text { Nurse Gloria always used to offer } \\
\text { coffee to her patients before starting } \\
\text { the appointment. She thought it } \\
\text { was a courteous attitude, but then } \\
\text { she reminded that coffee aggravates } \\
\text { the clinical picture of hypertensive } \\
\text { patients. She began to offer mate tea } \\
\text { instead of coffee to her patients. }\end{array}$ & Original card maintained & l \\
\hline 26 & $\begin{array}{l}\text { What are the necessary equipment } \\
\text { and environmental conditions for the } \\
\text { BP measurement? }\end{array}$ & $\begin{array}{l}\text { What are the necessary devices for the } \\
\text { indirect measurement of blood pressure } \\
\text { with auscultatory technique? }{ }^{(1-2)} \text {. }\end{array}$ & $\begin{array}{l}\text { Non-specific question about the } \\
\text { indirect measure of BP. Modification } \\
\text { necessary to achieve the research } \\
\text { objectives. }\end{array}$ \\
\hline 27 & $\begin{array}{l}\text { How many are the Korotkoff sounds? } \\
\text { What does each one mean? How } \\
\text { many Korotkoff sounds determine } \\
\text { blood pressure? }\end{array}$ & $\begin{array}{l}\text { During the admission of an adult patient } \\
\text { with high obesity degree, nurse Simone } \\
\text { identified that there were } 12 \times 23 \mathrm{~cm} \text { cuffs } \\
\text { in the sector. What are the alternative sites } \\
\text { she may use for the indirect measurement } \\
\text { in this situation?(1-2). }\end{array}$ & $\begin{array}{l}\text { The topic of the question is already } \\
\text { covered in another card. }\end{array}$ \\
\hline 28 & $\begin{array}{l}\text { Nurse Carol, during the BP } \\
\text { measurement, instructs her patients to } \\
\text { adopt correct and comfortable position, } \\
\text { either sitting, lying or standing, because } \\
\text { she understands that the blood pressure } \\
\text { values do not undergo alterations with } \\
\text { the change of position. }\end{array}$ & Original card maintained & / \\
\hline
\end{tabular}

Note: BP - Blood Pressure; SAH - Systemic Arterial Hypertension; HDP-Hypertensive Diseases of Pregnancy; SBP-Systolic Blood Pressure; DBP-Diastolic Blood Pressure.

In this context, it may be noted that only one of the cards was changed from the category REVERSE to LUCK. This was done in order to balance the attribution of points during the game.

\section{Game application}

Table 1 presents the frequency of errors and successes in the pre- and post-tests. It is observed that there was success in $93.3 \%$ of questions on the post-test, compared to the pre-test. In this observation, we highlight questions D1.4, D2.2 and D2.4, which went from $43.3 \%, 36.7 \%$ and $36.7 \%$ successes in the pre-test to $96.7 \%$,
96.7\% and $86.7 \%$ in the post-test, respectively; such as D3.3 and D3.4, from $40 \%$ and $23.3 \%$ to $93.3 \%$ and $56.7 \%$. Just question D1.2 had worsening of successes in the post-test and question D1.1 kept the same number of successes and errors in the post-test.

Participants' satisfaction regarding their knowledge about blood pressure is described in Table 2. We should note that, before the game, the amount of participants fully satisfied was $0 \%$, reaching $13.3 \%$ on the post-test. In addition, if we consider the degrees "totally satisfied" and "satisfied" as an appropriate result, it was observed increase from $23.3 \%$ in the pre-test to $96.7 \%$ in the post-test.

Table 1 - Absolute Frequency of successes at each multiple choice question in the pre-test and post-test, Campinas, São Paulo, Brazil, 2016

\begin{tabular}{ccccccccccccccccc}
\hline Step & Questions & D1.1 & D1.2 & D1.3 & D1.4 & D1.5 & D2.1 & D2.2 & D2.3 & D2.4 & D3.1 & D3.2 & D3.3 & D3.4 & D3.6 & D3.7 \\
\hline \multirow{2}{*}{$\begin{array}{c}\text { Pre-test } \\
\text { Post-test }\end{array}$} & Correct & 17 & 29 & 12 & 13 & 16 & 22 & 11 & 19 & 11 & 02 & 15 & 12 & 07 & 19 & 14 \\
& Correct & 17 & 27 & 16 & 29 & 23 & 24 & 29 & 28 & 26 & 17 & 19 & 28 & 17 & 26 & 16 \\
\hline
\end{tabular}


Table 2 - Participants' satisfaction regarding their knowledge about blood pressure in the pre-test and post-test, Campinas, São Paulo, Brazil, 2016

\begin{tabular}{lccccccc}
\hline & \multicolumn{3}{c}{ Pre-test } & \multicolumn{3}{c}{ Post-test } \\
\cline { 2 - 7 } Satisfaction degree & $\mathbf{n}$ & $\mathbf{\%}$ & $\begin{array}{c}\% \\
\text { cumulative }\end{array}$ & $\mathbf{n}$ & $\%$ & $\begin{array}{c}\% \\
\text { cumulative }\end{array}$ \\
\hline Totally satisfied & - & - & - & 4 & 13.3 & 13.3 \\
Satisfied & 7 & 23.3 & 23.3 & 25 & 83.3 & 96.7 \\
Little satisfied & 14 & 46.7 & 70.0 & 1 & 3.3 & 100.0 \\
Dissatisfied & 7 & 23.3 & 93.3 & - & - & 100.0 \\
Totally dissatisfied & 2 & 6.7 & 100.0 & - & - & 100.0 \\
\hline
\end{tabular}

In Table 3, it is possible to observe the level of the participants' consideration with respect to their theoretical knowledge about blood pressure before and after the game.

Table 3 - Degree assigned by participants to their theoretical knowledge about blood pressure in the preand post-test, Campinas, São Paulo, Brazil, 2016

\begin{tabular}{lcccccc}
\hline & \multicolumn{4}{c}{ Pre-test } & \multicolumn{3}{c}{ Post-test } \\
\cline { 2 - 7 } $\begin{array}{l}\text { Degree } \\
\text { assigned }\end{array}$ & $\mathbf{n}$ & $\%$ & $\begin{array}{c}\% \\
\text { cumulative }\end{array}$ & $\mathbf{n}$ & $\%$ & $\begin{array}{c}\% \\
\text { cumulative }\end{array}$ \\
\hline Great & - & - & - & 7 & 23.3 & 23.3 \\
Good & 5 & 16.7 & 16.7 & 21 & 70.0 & 93.3 \\
Regular & 18 & 60.0 & 76.7 & 2 & 6.7 & 100.0 \\
Bad & 6 & 20.0 & 96.7 & - & - & 100.0 \\
Very bad & 1 & 3.3 & 100.0 & - & - & 100.0 \\
\hline
\end{tabular}

In the pre-test, no participant considered his/her knowledge as Great, situation that changed in the post-test. Considering the degrees Great and Good as a desired result, the cumulative percentage was 6 times higher in the post-test in relation to the pre-test. No participant considered his/her knowledge as Bad or Very bad in the post-test.

In Table 4, we present the grades self-attributed by the participants (from 0 to 10 ) regarding their knowledge about BP measurement and the scores obtained in the answers to multiple choice questions.

It is possible to observe that the median values of the selfattributed grades increased between the pre- and the post-test, reaching a significant difference. Equally, the standard deviation decreased in both. Regarding the score, the minimum value more than doubled after application of the game, and the maximum reached $100 \%$ successes in the post-test, compared to $87 \%$ in the pre-test. The range decreased 4 points for the self-attributed grades and 2 points for the scores, demonstrating greater homogeneity. That change occurred mainly because of the minimum value increase. The interquartile range increased from 1.2 to 1.7 points for the self-attributed grades and from 1.5 to 2.1 for the scores. This reflects the improvement in self-assessment and scores of the participants, since they are classified from a higher level of grades in the post-test, expressed by the minimum values. One of the participants did not assign him/herself a grade.

Table 4 - Grades self-assessed by participants regarding their knowledge about theoretical aspects of blood pressure auscultatory measurement in the pre-test (Pre theory) and in the post-test (Post theory) and scores obtained in answers to the multiple choice questions in the pre-test (Pre Score) and post-test (Post Score), Campinas, São Paulo, Brazil, 2016

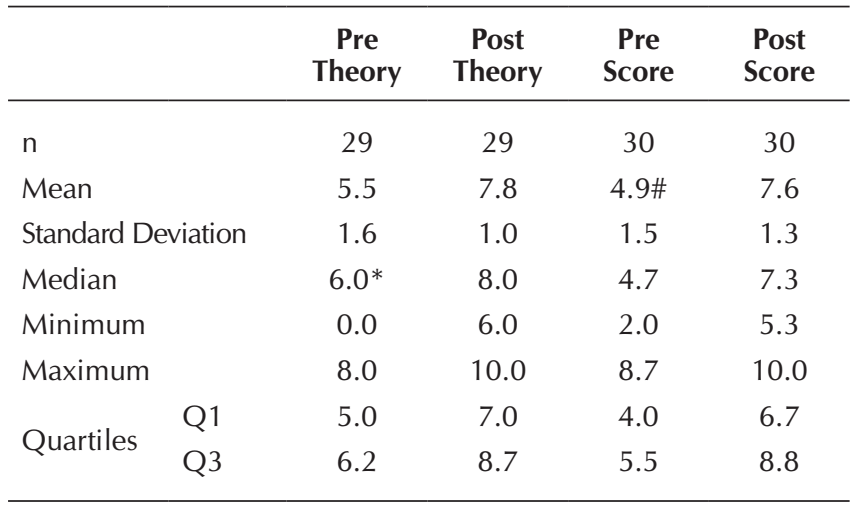

Note: $\# p=0.03$ (significant difference between the means of scores in the preand post-test - paired t-test); * $p<0.05$ (significant difference between the theory medians in the pre- and post-test - paired Wilcoxon test); $n$ - number of answers.

\section{DISCUSSION}

This study was conducted with the objective of adapting and revalidating the content of a previously structured game by means of altering the cards, making this game specific to theoretically teach the blood pressure auscultatory measurement. The modified game proved to be suited to achieve this objective, a conclusion that can be drawn from the improvement of evaluation parameters presented. Its importance is that this procedure is the most widely used method in health care locations and is also the most studied due to the mistakes made by health professionals, typically attributed to outdating, ignorance about the theory and inattention to the steps and care set by the Brazilian Hypertension Guidelines, causing false diagnoses and possible damage to the patient's health ${ }^{(1-2,5)}$. Teaching by the playful method can engage and entertain students, reinforcing concepts and teaching new knowledge, as well as allowing them to miss and hit, preparing the student for the actual practice ${ }^{(6)}$.

The content validation process used in this study followed the recommendations from the literature ${ }^{(7-8)}$. The initial approach was theoretical and performed exclusively by the authors, from the previous experience of one of them with the game application. The process of choosing the evaluators took into account, in particular, their experience with the implementation of the BP auscultatory measurement. Finally, quantitative and qualitative criteria have been complied with: the former criteria defined that the question would be accepted when there was agreement of at least $80 \%$ of the judges; the latter criteria became evident for the reformulation 
of questions that did not achieve this score, but still aroused interpretation doubts ${ }^{(8-9)}$.

During the game sessions, there was great entertainment among the participants, who showed interest in learning in order to give the correct answers during the matches. It is possible to assess that the game can be an effective teaching method ${ }^{(12)}$, which is suggested by the significant increase of the grades between the pre- and post-test, with medians of 4.7 and 7.3 , respectively. In addition, the pilot study did not show the need for further modifications to the bonus, reverse and luck cards.

The instrument used for the pre-test and post-test was adapted from another instrument submitted to refined validation process ${ }^{(5)}$. Some results obtained deserve to be discussed in particular.

An important point to be highlighted about the question D3.1 ("When checking the BP with the auscultation method, the gap or hole auscultation occurs between phases of the Korotkoff sounds") is the high percentage of errors in the pre-test $(93.3 \%)$, which means ignorance about the theory on the Korotkoff sounds ${ }^{(1-2)}$. Significant part of the interviewed participants reported they remembered having already studied this theory as undergraduates, but with common practice, such knowledge ended "falling into oblivion." Because of this, maybe the practice resulted in an inadequate technical performance, since if the presence of gap is not verified, the values obtained can be falsely low for the systolic or falsely high for the diastolic ${ }^{(1)}$. In the post-test that frequency dropped to $43.3 \%$, which strengthens the effectiveness and importance of the application of this kind of teaching strategy.

The question D2.2 also presented high level of errors in the pre-test $(63.3 \%)$; in the post-test this percentage fell to $3.3 \%$. This question refers to the need for calibration of aneroid devices. The alternatives were related to the time range recommended for performing calibration, and the correct answer was in item 3 ("Every 6 months"). According to data from Table 1, it follows that $63.4 \%$ answered incorrectly; of these respondents, $73 \%$ marked item 5 ("In accordance with the manufacturer guidelines"). This can lead to confusion because any electronic equipment has its instruction manual for a proper use. However, in the case of aneroid equipment for BP measurement, the National Institute of weights and measures establishes standards for quality assurance of these devices ${ }^{(10)}$.

On question D1.2 ("the preferred position to perform the blood pressure measurement is with the individual:") the correct answer would be "sitting." In the pre-test there was $96.6 \%$ of successes, however, after application of the game, this number declined to $90 \%$, being that three participants marked three options ("lying, sitting and standing"). This may have occurred because the participant did not carefully read the question in the post-test phase and must have considered that the BP can be checked in all these positions. However, the preferred position is sitting. Even though, we highlight that the measurement must be error-free regardless of the position used ${ }^{(1-2,5)}$. The result obtained may be indicating a difficulty in understanding the question or ignorance about positioning for BP checking.

The game, as a strategy of health education ${ }^{(12-14)}$, proved to be completely effective for questions D1.4, D2.4, D3.3, in which the percentages of successes from the pre-test to the post-test surpassed 50\%. Questions D1.4 and D2.4 were related to the cuff position on the arm and to the correct size, respectively. It is known that there are several determining factors of errors during BP measurement, related to the patient, equipment, measurement techniques, record of the values obtained and interpretation of results. Regardless of the sphygmomanometer model adopted, the use of a cuff with a size that is appropriate to the patient's arm is essential. The inflatable rubber bladder must correspond to at least $40 \%$ of the arm circumference and cover at least $80 \%$ of the arm extension. The use of cuffs smaller than recommended can overestimate the systolic blood pressure of 10 up to $50 \mathrm{mmHg}$, while the opposite may occur with larger cuffs applied to thin arms $^{(15)}$. Therefore, with the significant improvement of the successes in the post-test phase, it is expected that application of appropriate cuffs can alleviate the errors related to the devices ${ }^{(16)}$.

Question D3.3 was intended to assess the knowledge of participants about the BP measurement in alternative locations. In the pre-test, $60 \%$ made a mistaking by marking item 2 ("Verifies the BP with this cuff and uses the table of value correction"), which supposes ignorance and/or forgetfulness of the alternative sites for BP verification because the BP measurement teaching often does not include the training of students for the impossibility of measuring the brachial artery ${ }^{(15)}$.

It is observed in Table 3 that five participants in the pre-test considered their theoretical knowledge on BP measurement as good, 18 considered it as regular, six as bad and one as very bad. However, applying the grade range related to the concept elaborated by Almeida (Great = 8.0 -10.0; Good = 7.0 - 7.9; Regular $=5.0-6.9 ; \mathrm{Bad}=3.0-4.9 ;$ Very $\mathrm{Bad}=0.0-2.9)^{(5)}$ to the average score obtained in the pre-test (Table 4 ), these participants would be classified as bad, and at most, regular. It is assumed that this self-reported perception is related to the fact that these people perform the indirect BP measurement PA daily, confident in their knowledge. However, this game allows a theoretical approach, aspect in which they were still deficient, particularly in the pre-test. National studies have already observed gaps in theoretical knowledge of health professionals on the BP auscultatory measurement ${ }^{(5,15-16)}$.

Participation in the game enabled immediate improvement in the performance of participants in the score and grade attributed in the post-test (Table 4) and in personal satisfaction (Table 2). During the game, participants commented on how this simple playful method managed to clarify the theoretical aspects of the BP auscultatory measurement. The satisfaction was also accompanied by the intention of participants to use this game in their workplaces to invest in permanent education of their colleagues.

\section{Study limitations}

As limitation of this research, we may point out the small number of participants. However, this is a pilot study, carried out for multiple purposes, among them the enhancement of the instrument under test. Another limitation refers to the absence of reapplication of the assessment instrument at a later time, such as 30 days after application of the game.

\section{Contributions to the field of nursing, health or public policy}

This strategy can help to better define its effectiveness, however, it is not suitable for a pilot study. Successive applications 
and use in other researches with more comprehensive and heterogeneous samples can highlight points in which some adjustments are necessary and can also optimize the performance of this instrument.

\section{CONCLUSION}

The results allow concluding that the use of this game as a teaching-learning strategy was effective to significantly increase the theoretical knowledge related to the BP auscultatory measurement in the sample under study. According to participants, the game increased their interest in learning and brought the assurance of making mistakes without consequences for the patient. The dispute increased the motivation to learn. The number of errors in the pre-test was high, but the game application proved to be able to reduce them, which reinforces the need and importance of applying techniques such as that in the teachinglearning process of the BP measurement.

\section{ACKNOWLEDGEMENTS}

The authors thank the original game authors, especially Livia Zulmyra Cintra Andrade and Viviane Martins da Silva. They also thank Thaís Moreira São João for the collaboration.

\section{REFERENCES}

1. Sociedade Brasileira de Cardiologia. Sociedade Brasileira de Hipertensão. Sociedade Brasileira de Nefrologia. $7^{\mathrm{a}}$ Diretrizes Brasileiras de Hipertensão. Arq Bras Cardiol [Internet]. 2016[cited 2016 Nov 16];107(3supl.):1-104. Available from: http:// publicacoes.cardiol.br/consenso/2016/Diretriz_hipertensao_associados.pdf

2. Sociedade Brasileira de Cardiologia. Sociedade Brasileira de Hipertensão. Sociedade Brasileira de Nefrologia. VI Diretrizes Brasileiras de Hipertensão. Arq Bras Cardiol [Internet]. 2010[cited 2016 Oct 16];95(1supl.):1-51. Available from: http://publicacoes. cardiol.br/consenso/2010/Diretriz_hipertensao_associados.pdf

3. Nascimento LR, Molina MCB, Faria CP, Cunha RS, Mill JG. Reproducibility of arterial pressure measured in the ELSA-Brasil with 24-hour pressure monitoring. Rev Saúde Pública [Internet]. 2013 [cited 2016 Oct 13];47(2):113-21. Available from: http://www. scielo.br/pdf/rsp/v47s2/0034-8910-rsp-47-00-2-0113.pdf

4. Alavarce DC, Pierin AMG. Development of educational hypermedia to teach an arterial blood pressure measurement procedure. Rev Esc Enferm USP[Internet]. 2011 [cited 2016 Oct 13];45(4):939-44. Available from: http://www.scielo.br/pdf/reeusp/v45n4/ v45n4a21.pdf

5. Almeida TCF, Lamas JLT. Nurses of Adult Intensive Care Unit: Evaluation about Direct and Indirect Blood Pressure Measurement. Rev Esc Enferm USP[Internet]. 2013 [cited 2016 Oct 13];47(2):369-76. Available from: http://www.scielo.br/pdf/reeusp/v47n2/14.pdf

6. Andrade LZC, Freitas DT, Holanda GF, Silva VM, Lopes MVO, Araújo TL. Desenvolvimento e validação de jogo educativo: medida da PA. Rev Enferm UERJ[Internet]. 2012 [cited 2016 Oct 13];20(3):323-7. Available from: http:// www.facenf.uerj.br/ v20n3/v20n3a07.pdf

7. Oliveira MS, Fernandes AFC, Sawada NO. Manual educativo para o autocuidado da mulher mastectomizada: um estudo de validação. Texto Contexto Enferm[Internet]. 2008 [cited 2016 Oct 13];17(1):115-23. Available from: http://www.scielo.br/pdf/tce/ v17n1/13.pdf

8. Alexandre NMC, Coluci MZO. Validade de conteúdo nos processos de construção e adaptação de instrumentos de medidas. Ciênc Saúde Colet[Internet] 2011 [cited 2016 Oct 13];16(7):3061-8. Available from: http://dx.doi.org/10.1590/ S1413-81232011000800006

9. Frota NM, Barro LM, Araújo, TM, Lopes, MVO, Almeida, PC, Caetano, JA. Validation of educational hypermedia about peripheral venipuncture. Texto Contexto Enferm [Internet]. 2015[cited 2016 Oct 13];24(2):353-61. Available from: http://www.scielo.br/pdf/ tce/v24n2/0104-0707-tce-24-02-00353.pdf

10. Pierin AMG, Mion Junior D. Como avaliar a calibração dos aparelhos de medida da pressão arterial. Rev Bras Hipertens[Internet] 2000 [cited 2016 Oct 13];7(4):399-400. Available from: http://departamentos.cardiol.br/dha/revista/7-4/017.pdf

11. Gusmão JL, Cavagioni LC, Colósimo FC, Silva SSBE, Serafim T, Toma GA, et al. Os esfigmomanômetros de coluna de mercúrio devem ser eliminados da prática clínica? Rev Hipertens [Internet] 2008 [cited 2016 Oct 13];11(1):20-6. Available from: http:// www.sbh.org.br/revistas/2008/revistahipertensao1 2008.pdf

12. Gurgel PC, Fernandes MC. Educational Games in Nursing Teaching of Public Health: experience report. Rev Enferm UFPE[Internet]. 2015[cited 2016 Nov 16];9(9):9320-3. Available from: http://www.revista.ufpe.br/revistaenfermagem/index,php/revista/article/ viewFile/6724/pdf_8598

13. Holanda VR, Pinheiro, AKB. Comparison of learning strategies in face-to-face and online courses on sexually transmitted diseases. Texto Contexto Enferm[Internet]. 2015[cited 2016 Oct 13];24(2):530-8. Available from: http://www.scielo.br/pdf/tce/v24n2/ pt_0104-0707-tce-24-02-00530.pdf

14. Barbosa SM, Dias FLA, Pinheiro AKB, Pinheiro PNC, Vieira NFC. Jogo educativo como estratégia de educação em saúde para adolescentes na prevenção às DST/AIDS. Rev Eletr Enferm[Internet]. 2010[cited 2016 Oct 13];12(2):337-41. Available from: http:// 
dx.doi.org/10.5216/ree.v12i2.6710

15. Silva RCG, Guerra GM. Aspectos relevantes no preparo do paciente para a medida da pressão arterial. Rev Hipertens[Internet]. 2011[cited 2016 Oct 13];14(2):14-20. Available from: http://www.sbh.org.br/pdf/2012_2.pdf

16. Oliveira TMF, Almeida TCF. Adequação do manguito durante a medida da pressão arterial: uma revisão integrativa. Ciênc Saúde[Internet]. 2015[cited 2016 Oct 13];8(1):35-41. Available from: http://dx.doi.org/10.15448/1983-652X.2015.1.19419 